\title{
Drought assessment for $k$ harif rice using standardized precipitation index (SPI) and vegetation condition index (VCI)
}

\author{
DEEPA B. KAMBLE ${ }^{1}$, SHWETA GAUTAM ${ }^{1}$, HIMANI BISHT ${ }^{2}$, SHRADDHA RAWAT ${ }^{1}$ \\ and ARNAB KUNDU ${ }^{3}$ \\ ${ }^{1}$ Department of Environmental Sciences and Natural Resource Management, ${ }^{3}$ Centre for Geospatial Technologies, \\ Sam Higginbottom University of Agriculture, Technology and Sciences, Allahabad, Uttar Pradesh \\ ${ }^{2}$ Water Technology Centre, ICAR-IARI, New Delhi, India \\ Corresponding author E-mail:gautamshweta808@gmail.com
}

\begin{abstract}
The monthly weather data for 31 years from 1985-2015 was used to analyze the extent of meteorological drought using standardized precipitation index (SPI) over Allahabad, Kanpur and Lucknow. MODIS NDVI data from 2000-2015 was used for monitoring of agricultural drought through NDVI based vegetation condition index ( $\mathrm{VCl}$ ) for all the three districts. The monthly SPI and $\mathrm{VCI}$ values from July to October were correlated with productivity index (PI) of kharif rice.Both the indices (SPI and VCI) were positively correlated with PI for all the districts. In Allahabad SPI and VCI during September month showed a significant correlation $\left(0.70^{* *} \& 0.61^{*}\right)$ while in Kanpur VCI during October and SPI of July and August were significantly correlated with $\mathrm{PI}$ of kharif Rice. The multiple regression equation developed for predicting kharif rice PI in Allahabad, Kanpur and Lucknow districts explained 69 to 76 per cent variability in $\mathrm{PI}$.
\end{abstract}

Keywords : Drought indices, standardized precipitation index (SPI), vegetation condition index (VCI), productivity index $(\mathrm{PI})$.

Drought is a recurring major natural climatic hazard that occurs in almost every climatic zone around the world and causing socio-economic challenges. It leads to increase food prices, food insecurity, poverty and famine which make it the worst among all the natural hazards.

Drought monitoring is an essential component for contingency planning of crop suffered due to water stress (Sahu et al., 2018) and usually carried out using drought indices/indicators. The standardized precipitation index (SPI) is a powerful and simple index as only rainfall is required for its calculation(McKee et al., 1993). The SPI of different time scales were used to study the impact on climates, crops and availability of water resources for example, 1- or 2-month SPI for meteorological drought, from 1-month to 6-month SPI for agricultural drought, and 6-month up to 24-month SPI or more for hydrological drought analyses (WMO, 2012). Lee and Dang (2018) used different times scale of SPI to characterize the drought in Vietnam, While Chaudhari and Dadhwal (2004) used. SPI to study impact on production of major crops in India. Satellite data are used to develop drought monitoring indices such as normalized difference vegetation Index (NDVI) and vegetation condition index (VCI) etc for identifying agricultural drought in different regions with varying ecological conditions (Amri et al.,2010; Ghaleb et al., 2015 and Dutta et al., 2015). Therefore, the present study was conducted to assess the pattern and frequency of drought and its relationship with kharif rice productivity in Allahabad, Kanpur and Lucknow districts of Uttar Pradesh by using two widely used indices viz. SPI and VCI.

\section{MATERIALS AND METHODS}

\section{Study area}

The study area is comprised of three districts of Uttar Pradesh, namely Allahabad, Kanpur and Lucknow.The districts Allahabad and Kanpur belong to the tract known as the lower Doab lying between the Ganga and the Yamuna rivers while Lucknow is situated on the bank of river Gomati.The region characterized by semi-arid and subhumid conditions. The mean annual rainfall varies between 700 and $1,000 \mathrm{~mm}$. The general description of the location is shown in Table 1.

\section{Standardized participation index (SPI)}

In order to assess the meteorological drought for the 
Table 1: General description of the study area

\begin{tabular}{lllllll}
\hline Districts & Latitude & Longitude & Altitude $(\mathrm{m})$ & Area $(\mathrm{sq} . \mathrm{km})$. & Rainfall $(\mathrm{mm})$ & Average temperature $\left({ }^{\circ} \mathrm{C}\right)$ \\
\hline Allahabad & $25.45^{\circ} \mathrm{N}$ & $81.85^{\circ} \mathrm{E}$ & 98 & 5425 & 800.9 & 25.7 \\
Kanpur & $26.5^{\circ} \mathrm{N}$ & $80.33^{\circ} \mathrm{E}$ & 133 & 3,146 & 657.4 & 25.5 \\
Lucknow & $26.85^{\circ} \mathrm{N}$ & $80.95^{\circ} \mathrm{E}$ & 252 & 2,528 & 721.1 & 25.5 \\
\hline
\end{tabular}

Table 2: Categorization of drought by VCI values

\begin{tabular}{ll}
\hline Drought Class & VCI \\
\hline Extreme & $<10$ \\
Severe & $<20$ \\
Moderate & $<30$ \\
Mild & $<40$ \\
No drought & $\geq 40$ \\
\hline
\end{tabular}

study area, SPI values have been calculated by using monthly rainfall data. The monthly rainfall data of 31 years (19852015) of Allahabad, Kanpur and Lucknow were collected from India Meteorological Department (www.imd.gov.in) and monthly SPI of four month viz. July, August, September and October was calculated with the help of spi_sl_6 program developed by the National Drought Mitigation Centre, University of Nebraska-Lincol (http:// ccc.atmos.colostate.edu/spi.php).

\section{Calculation of vegetation condition index (VCI)}

The MODIS (Moderate Resolution Imaging Spectroradiometer) NDVI data (http://daacmodis.ornl.gov) of MOD13Q1 satellite from the year 2000 to 2015 were used to calculate vegetation condition index (VCI) for all three districts. Global MOD13Q1 data are provided every 16 days at 250-meter spatial resolution as a gridded level-3 product in the sinusoidal projection. $\mathrm{VCI}$ is found more suitable for agricultural drought assessment index as compare to NDVI (Kogan, 1990) which was calculated by using the formula:

$$
V C I=\frac{(N D V I i-N D V I m i n)}{(N D V I m a x-N D V I m i n)} * 100
$$

where, $\mathrm{NDVI}_{\max }$ and $\mathrm{NDVI}_{\min }$ represent maximum and minimum NDVI of each pixel calculated for each month and $\mathrm{NDVI}_{\mathrm{i}}$ represents the NDVI of current month. The drought classification based on VCI values were shown in Table. 2.

\section{Productivity index (PI)of kharif rice}

The yield data of Kharif rice from 2000-2015 were collected for all three districts (Allahabad, Kanpur \& Lucknow) from the website:www.eands.dacnet.nic.in. The trend yields were calculated on the basis of yield data of Kharif rice and then fitted with the linear curve (Subash and Mohan, 2011). Technological productivity (TPi) is given as:

$$
\mathrm{TPi}=\mathrm{abi}
$$

Where, $\mathrm{a}$ and $\mathrm{b}$ are the constants determined empirically, $i=1,2,3 \ldots \ldots$. representing the years from 2000 to 2015 for rice crop.

The productivity index(PI) for rice was taken as the percentage of the technological trend productivity (exponential or linear) to the actual productivity. The normalized PI for the $i^{\text {th }}$ year is given by following formula.

$$
\mathrm{PIi}=\frac{(\mathrm{Pi}-\mathrm{TPi}) * 100}{\mathrm{TPi}}
$$

Where, $\mathrm{Pi}$ is the actual productivity for the $\mathrm{i}^{\text {th }}$ year and TPi is the technological trend productivity for the $\mathrm{i}^{\text {th }}$ year.

\section{Correlation and regression analysis}

SPI and VCI during different months (July, August, September \& October) were correlated with PI of rice for each district and a stepwise multivariate statistical regression was carried out taking SPI and VCI as independent variables and PI as a dependent variable for the period 2000 to 2015.The representative expression of multivariate model is:

$$
\mathrm{Y}=\mathrm{b}_{0}+\mathrm{b}_{1} \mathrm{X}_{1}+\mathrm{b}_{2} \mathrm{X}_{2}+\ldots \ldots \ldots+\mathrm{b}_{\mathrm{n}} \mathrm{X}_{\mathrm{n}}
$$

Where, $\mathrm{Y}=$ dependent variable i.e.PI, $\mathrm{b}_{0}=$ estimated constant, $b_{n}=$ estimate coefficients and $X_{n}=$ independent variables i.e. SPI and VCI.

\section{RESULTS AND DISCUSSION}

\section{Standardized precipitation index (SPI)}

The frequency of drought from July to October for all the 3 districts has been shown in Table 3. The results indicated that the frequency of moderate drought events was found more than the severe and extreme drought events. The SPI classes fell under dry category (where SPI $<-0.99$ ) were 29, 9 and 16 per cent of study period (1985-2015) during July, August and September, respectively for 
Table 3: Drought frequency classes of SPI during 1985-2015

\begin{tabular}{|c|c|c|c|c|c|c|c|}
\hline \multirow[b]{2}{*}{$\begin{array}{l}\text { Station/ } \\
\text { Month }\end{array}$} & \multicolumn{7}{|c|}{ SPIClasses } \\
\hline & $\begin{array}{r}\text { Extremely } \\
\text { wet } \\
(>2.0)\end{array}$ & $\begin{array}{r}\text { Very } \\
\text { wet } \\
(1.5 \text { to } \\
1.99) \\
\end{array}$ & $\begin{array}{r}\text { Moderately } \\
\text { wet } \\
(1.0 \text { to } \\
1.49)\end{array}$ & $\begin{array}{r}\text { Near } \\
\text { normal } \\
(-0.99 \text { to } \\
0.99)\end{array}$ & $\begin{array}{r}\text { Moderately } \\
\text { dry } \\
(-1.0 \text { to } \\
-1.49)\end{array}$ & $\begin{array}{r}\text { Very dry } \\
(-1.5 \text { to } \\
-1.99)\end{array}$ & $\begin{array}{r}\text { Extremely } \\
\text { dry } \\
(<-2.0)\end{array}$ \\
\hline \multicolumn{8}{|l|}{ Allahabad } \\
\hline July & 0 & 3 & 13 & 55 & 23 & 3 & 3 \\
\hline August & 3 & 3 & 7 & 78 & 3 & 0 & 6 \\
\hline September & 3 & 10 & 0 & 71 & 13 & 0 & 3 \\
\hline October & 3 & 3 & 19 & 75 & 0 & 0 & 0 \\
\hline \multicolumn{8}{|l|}{ Kanpur } \\
\hline July & 3 & 3 & 3 & 72 & 13 & 3 & 3 \\
\hline August & 0 & 3 & 7 & 68 & 16 & 3 & 3 \\
\hline September & 3 & 0 & 10 & 74 & 6 & 7 & 0 \\
\hline October & 3 & 6 & 7 & 84 & 0 & 0 & 0 \\
\hline \multicolumn{8}{|l|}{ Lucknow } \\
\hline July & 0 & 0 & 6 & 75 & 10 & 3 & 6 \\
\hline August & 3 & 3 & 0 & 78 & 10 & 3 & 3 \\
\hline September & 3 & 0 & 6 & 72 & 10 & 3 & 6 \\
\hline October & 3 & 3 & 13 & 81 & 0 & 0 & 0 \\
\hline
\end{tabular}

Allahabad. For Kanpur, the dry category of drought were 19, 22 and 13 per cent at Lucknow it's were 19, 16, 19 per cent during July, August and September, respectively. Whereas, there was no drought found in the month of October.

\section{Validation of SPI and VCI index for drought monitoring}

The SPI and VCI values of July, August, September and October were compared during drought year (2002)and normal year (2003) for all the three stations. The results indicated from Fig. 1 that in the month of July the severe and extreme drought events were experienced during 2002 with the SPI value of $-1.76,-3.46$ and -1.7 for Allahabad, Kanpur and Lucknow, respectively. Similarly, in 2002 July month (Fig. 2) the VCI showed mild drought conditions in Lucknow ( VCI $=25 \%)$ and severe drought conditions in Kanpur $(\mathrm{VCI}=10 \%$ ). Many studies also showed that during the year 2002, the July month which contributes significant monsoon rainfall, received very less rainfall in most parts of the country. Due to meager rainfall during the July month of the year 2002, the year was considered as one of the worst drought year which leads to very poor crop growth and consequently the less production that year.It was also observed that during the normal year 2003 both VCI and SPI values fell under no drought category. Among all the months, October was the least critical month for drought. The results indicated that the growth and development of crops is directly related to rainfall received during the crop season.Therefore, the findings justify the usefulness SPI and VCI index for identifying meteorological and agricultural drought in the study area.

\section{Productivity index (PI) of kharif rice}

In case of Allahabad, 10 years fell under deficit rice productivity with minimum value of -19.03 during 2015 . Similarly for Kanpur the minimum value (-18.23) of PI was observed in 2015 . These results showed conformity as year 2015 was one of the severe drought years among the study period. But in case of Lucknow seven years fell under deficit rice productivity with minimum value of -24.20 in the year 2000 .

\section{Relationship of SPI and VCI with productivity index (PI) of rice}

Correlation analysis was carried out for month of July to October between SPI, VCI and PI of rice from the period 2000-2015 in all three districts (Table 4). Correlation 




Fig. 1: Comparison of SPI during drought year (2002) and normal year (2003) in Allahabad, Kanpur and Lucknow

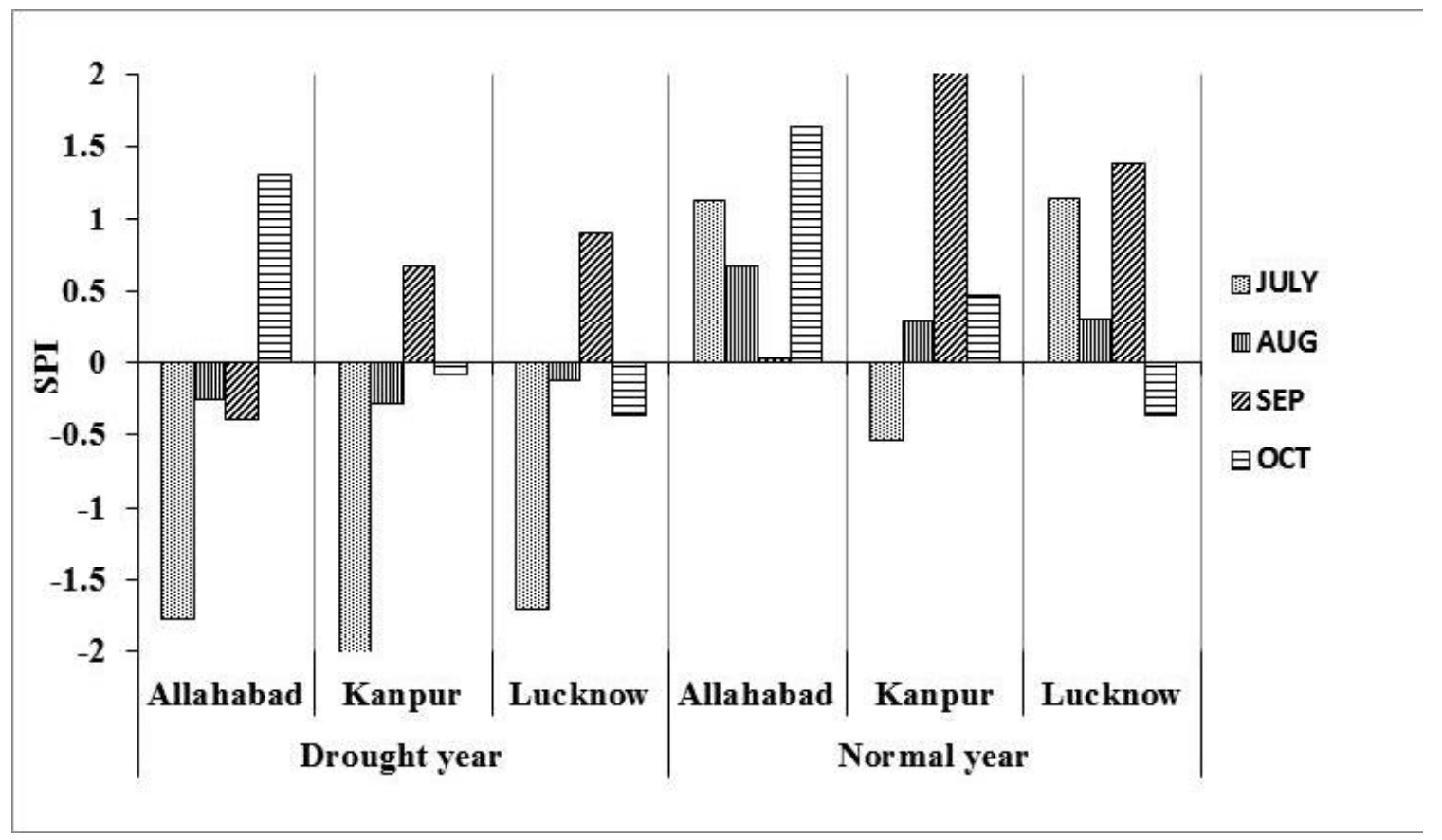

Fig.2: Comparison of VCI during drought year (2002) and normal year (2003) in Allahabad, Kanpur and Lucknow

between VCI and PI was found to be positive from July to September for all the three districts. There was significant correlation found between VCI and PI in September (0.62) for Allahabad and October (0.66) for Kanpur. A positive correlation was observed between SPI and PI in monsoon months (July-September) for all three districts while it was found significant for Allahabad in September (0.70) and for
Kanpur in July (0.52) and August (0.51). This difference in significant relationship among difference districts may be due to rainfall variability. However, other factors such as air temperature, availability of fertilizers, chemical, seeds etc. also affect the productivity of rice. These findings are in conformity with the findings of Subash and Mohan (2011) as they found SPI and productivity index of kharif rice 
Table 4: Correlation coefficient between drought indices and productivity index of kharifrice

\begin{tabular}{lccc}
\hline Drought Indices & \multicolumn{3}{c}{ Districts } \\
\cline { 2 - 4 } & Allahabad & Kanpur & Lucknow \\
\hline VCI_July & 0.03 & 0.03 & 0.10 \\
VCI_August & 0.02 & 0.23 & 0.27 \\
VCI_September & $0.61^{*}$ & 0.35 & 0.32 \\
VCI_October & 0.28 & $0.66^{* *}$ & 0.15 \\
SPI_July & 0.26 & $0.52^{*}$ & 0.18 \\
SPI_August & 0.12 & $0.51^{*}$ & 0.27 \\
SPI_September & $0.70^{* *}$ & 0.30 & 0.45 \\
SPI_October & -0.17 & -0.07 & 0.22 \\
\hline
\end{tabular}

$*$ correlation at $5 \%$ significance level, $* *$ correlation at $1 \%$ significance level

Table 5: Equation for predicting productivity index of rice

\begin{tabular}{lll}
\hline Districts & Regression equation & $\mathrm{R}^{2}$ \\
\hline Allahabad & $\mathrm{PI}=-19.73+(5.36) * \mathrm{SPI}_{\mathrm{Sep}}+(0.38) * \mathrm{VCI}_{\text {Sep }}$ & 0.69 \\
Kanpur & $\mathrm{PI}=20.31+(3.96) * \mathrm{SPI}_{\mathrm{Jul}}+(4.54) * \mathrm{SPI}_{\text {Aug }}+(0.46) * \mathrm{VCI}_{\text {Oct }}$ & 0.76 \\
Lucknow & $\mathrm{PI}=6.86+(5.38) * \mathrm{SPI}_{\mathrm{Sep}}+(0.17) \mathrm{VCI}_{\mathrm{Jul}}-(0.27) \mathrm{VCI}_{\text {Sep }}$ & 0.71 \\
\hline
\end{tabular}

significant at $\mathrm{p}<0.05$

offered as a good indicator of rice productivity variations in Indo-Gangetic Region (IGR) of India. Hence the success or failure of the kharifrice in any year is always viewed with utmost anxiety as they are closely linked to the behavior of the southwest monsoon rains. Similarly Dutta et al. (2015) conducted a study over Rajasthan and found that the VCI values of normal year (2003) and drought year (2002) were compared with meteorological based SPI rainfall anomaly index and yield anomaly index and a good agreement was found among them.

The multiple regression equations for productivity index (PI) of kharif rice versus monthly SPI and monthly vegetation condition index (VCI) for kharif season (JulyOctober) were developed drought conditions and are shown in (Table 5).VCI and SPI have been considered as independent variable and PI of kharif rice as dependent variable. It was observed that PI, monthly SPI and VCI during July to October showed a significant $\left(\mathrm{R}^{2}=0.69\right)$ relationship for Allahabad. This indicated that the monthly distribution of monsoon rainfall in terms of the SPI and monthly NDVI explained 69 per cent of the yield variability in kharif rice productivity. The results for Kanpur revealed that SPI for July, August and VCI for October month have a significant $\left(\mathrm{R}^{2}=0.76\right)$ relationship with $P I$ which defines the importance of rainfall in terms of monthly SPI and VCI for the variability of rice productivity for Kanpur. Lucknow also showed a significant relation $\left(\mathrm{R}^{2}=0.71\right)$ indicating the importance of rainfall in terms of SPI for September and VCI for July and August month to the kharif rice productivity indicating the 71 per cent influence of rainfall on the kharif rice productivity. Thus the monthly SPI and VCI based multiple regression equation are suitable for estimating kharif rice.

\section{CONCLUSION}

It can be concluded from the study that standardized precipitation index (SPI) and remote sensing index (VCI) shares a strong correlation where water is alimiting factor for plant growth. More evenly spread rainfall throughout the growing season, are beneficial to kharif rice. Our methodology is easy, rapid, straight forward and mainly fed by rainfall and remote sensing data. However, the more precise results depend on the spatial resolution of satellite data and quality of the input data than on the methodology itself. For future studies, higher spatial resolutions and other drought indices are suggested to achieve actual drought status for a particular region.

\section{REFERENCES}

Amri, R., Zribi, M., Chabaane, Z. L., Duchemin, B., Gruhier, C. and Chehbouni, A. (2010). Analysis of Vegetation 
Behavior in a North African Semi-Arid Region, Using spot-vegetation NDVI data. Remote Sens., 3: 25682590 .

Chaudhari, K.N. and Dadhwal, V.K. (2004). Assessment of impact of drought - 2002 on the production of major Kharif and rabi crops using standardized precipation index. J. Agrometeorol., 6(special issue):10-15.

Dutta, D., Kundu, A., Patel, N.R., Saha, S.K. and Siddiqui, A.R. (2015). Assessment of agricultural drought in Rajasthan (India) using remote sensing derived Vegetation Condition Index (VCI) and Standardized Precipitation Index (SPI), Egypt. J. Remote Sens. Space. Sc, 18: 5363.

Ghaleb, F., Mario, M. and Sandra,A.N. (2015). Regional LandsatBased Drought Monitoring from 1982 to 2014. Climate, 3: 563-577.

Kogan, F.N. (1990). Remote sensing of weather impacts on vegetation in non-homogeneous areas. Int. J. Remote Sens., 11 (8), 1405-1419.
Lee, S.K. and Dang, T.A. (2018). Evaluating drought events under influence of El-Nino phenomenon: Acase study of Mekong Delta area, Vietnam. J. Agrometeorol., 20(4):275-279.

McKee, T.B., Doesken, N.J. and Kleist, J. (1993). The relationship of drought frequency and duration to time scales. In: Eighth Conference on Applied Climatology. American Meteorological Society, Anaheim, CA, 179-186.

Sahu, Y. K., Mishra, E.P. and Rawat, S. (2018). Quantification of crop water stress index (CWSI) for maize crop under different microclimatic conditions of Allahabad. $J$. Agrometeorol., 20 (special issue): 368-371.

Subash, N. and Mohan, R. H. S. (2011). A Simple Rationally Integrated Drought Indicator for Rice-Wheat Productivity. Water ResourManag, 25: 2425-2447.

WMO, (2012). Standardized Precipitation Index User Guide 116. 